\title{
The Indecisive Feminist: Study of Anne Sexton's Revisionist Fairy Tales
}

\author{
Nadia Fayidh Mohammed \\ College of Arts, University of Mustanserya \\ Baghdad, Iraq. \\ E-mail: nadia_faydh@yahoo.com
}

\author{
Doi:10.7575/aiac.alls.v.6n.1p.31 \\ URL: http://dx.doi.org/10.7575/aiac.alls.v.6n.1p.31
}

Received: $12 / 09 / 2014$

Accepted: 15/11/2014

\begin{abstract}
Fairy tales to female writers are major resource for their abundant writings, but for the feminist poets since 1960s, they become essential subject matter to often deal with in their literary production. With the motivation to address the conventional tradition of patriarchal society, and re-address the stereotype females inhabiting these tales, feminist writers set upon revealing the underlying sub-context of these tales, presenting them with more adult-suited themes. Anne Sexton's Transformation is a pioneering revision of Grimm's fairy tales in which the poet does not only satirize the patriarchal society she grew up in, but she also rejects the female stereotype that her upbringing intended her to be. In the following paper, the feminist messages which Sexton's fairy tales intended to deliver are examined to reveal the poet's position concerning feminism and her relationship with female role-models and the male figures she presents in her fairy tales.
\end{abstract}

Keywords: Anne Sexton, feminism, fairy tales, revisionism, postmodernist poetry, Transformations

\section{Introduction}

Gina Dalfonzo, in reviewing Disney's new fairytale-based movie "Frozen", reported that having the prince charming turning to villain was the scariest element in the movie [Dalfonzo, 2013: 1+]. Fairy tales are meant to provide their readers with comfort and assuring moral values that support the ideal world many parts hope their children to grow in. However, fairy tales today, no matter what is their media, fail to provide their readers with the same assuring world they used to provide in the 19th century narratives recorded by the Brothers Grimm.

The maternal wisdom, the heroism of the prince charming, the salvation guaranteed by the dominion of the male-figure and the happy endings within conventional social norms, which were traditionally underlying elements of fairy tales, are shattered away by more gender-oriented narratives. After the second wave of feminism during the end of 1960s, many female writers ventured on exploring and revising the stereotypes supported by these fairy tales, defying the expectedly heroic boy/prince charming, the silent accepting girl, and most importantly, the over-estimated happy endings [Sage, 1999: 231-2]

Feminist studies and criticism assign political and aesthetic reasons behind the widely-spread tendency to re-write fairy tales. On one hand, there is the feminist agenda of women writers who want to assert the change of women's roles and images in modern society. Alicia Ostriker, the feminist poet and activist, asserts that the main reason behind fairy-tales revision is "the challenge to and correction of gender stereotypes" which these fairy tales embody [Ostriker, 1982b: 73].

Along the political agenda of feminism, there is an aesthetic motive that is related to the position female writers used to occupy in literary canon. For many centuries, female writers were excluded from serious literary studies simply because they write 'personal' poetry and by removing the poet's self, as female poets try to in their fairy-tales revisions [Brinton, 2009:49], and re-write established narratives, they assume literary status [Ostriker, 1982b: 73].

One of the pioneering works in fairy-tales revisions is Anne Sexton's Transformations (1971) which "broke the spell" of Grimm's' fairy tales [Sage: 233]. In her tales, Sexton satirizes traditional paradigms of heroism, romance and virtues, transforming them to tales of greed, incest, and violence. Her chief motive was exploring material outside her troubled reality and her self-crises after engaging most of her poetic energy in "confessing" intimate details of her life.

However, Anne Sexton's personal life continued to influence her narrative of the tales and cast the same shadows of uncertainty and ambivalence on her attitude toward the characters inhabiting fairy tales. The following discussion of Anne Sexton's fairy tales argues that in spite of the poet's attempts to assert a feminist attitude and establish the objectivity which has been missing in her early poetry, Transformations is haunted by the same dilemma and struggle for identity that Sexton's early poems have often expressed.

\section{Sexton and Feminist Poetry}

Sexton started her career as a poet after the advice of her therapist who encouraged her to use writing as remedy for her psychological crisis. Writing poetry became her distraction and outlet when she fell into depression or was 
overwhelmed by imaginary voices that pushed her toward suicide. When these attempts proved useful, Sexton took serious steps to develop her talent: she enrolled in several workshops, among which Robert Lowell's seminar of writing, where she met many distinguished literary figures who later became of great influence on her career; among whom were Sylvia Plath and John Starbuck. Persistence for writing poetry led to Sexton's first book To Bedlam and Part Way Back [Kimmelman, 2005: 454].

By the time Sexton was publishing her work, "confessional" poetry was finding increasing appeal with many American poets. Though important literary names became associated with the movement, Anne Sexton stood as "more consistently and uniformly confessional" than the others [quoted in Gill, 2004: 61]. Among the leading figures of confessional poetry were Lowell and Plath who tried to link their poetry to general cultural subjects; however, Sexton kept her work quite personal and autobiographical. Because the latter's poems appeared to be more confessional than others revealing their author's sense of guilt and pain, Sexton bereading Anne Sexton's poems gives insight to the poet's struggle with mental illness, depression and her several attempts to end her life. Nevertheless, the strongest of Sexton's confessional works are these that tackle taboo subjects which rarely found a prior expression in poetry. Sexton's greatest achievement at that time was her direct and outward expression of intimate details of the female body and sexuality [Sage: 146]

During the 1960s, when feminist literature was still gathering audience and female writers were trying to achieve literary recognition equal to their male peers, many of Anne Sexton's poems published at that time aroused controversy among her critics, males or females. Maxine Kumin, he colleague in poetry workshops, mentions in her introduction to the collected poems of Sexton that Louise Simpson and James Dickey, both were distinguished poets and critics then, gave unfavorable reviews of Sexton's poems because of their dwelling "more insistently on the pathetic and disgusting aspects of bodily experience" [quoted in Kumin, 1981: xiv-xx]. Even the pioneer of confessional poetry, Robert Lowell, who was one of the major influences on Sexton's early work, was not exactly pleased with the forward nature of her topics or the outright exposition of the female body which Sexton expressed in poems like "Song to My Uterus" or "Menstruation at Forty". He states

Many of her most embarrassing poems would have been fascinating if someone had put them in quotes, as the presentation of some character not the author [quoted in Kumin: xx].

However, these poems and most of her early works gained Anne Sexton a distinguished place within feminist circles who found in her poetry unprecedented representation of women's situation during the transitional decades of feminism. Alicia Ostriker, who is known for her feminist writings, asserts that Sexton's "biological" poetry "challenges our residual certainties that the life of the body should be private and not public, and that women especially should be seen not heard, except among each other, talking about their messy anatomies [Ostriker, 1982a: 11].

Anne Sexton, however, did not intend her writings to be feminist, or have political agenda. Her biographer asserts "Anne Sexton did not claim to be a feminist herself, but she was a leader of the pack nonetheless --one of the first American poets whose bold arts made feminist issues accessible to middle class white women" [Middlebrook, 1996: 125]. She preferred to call herself "an imagist who deals with reality and its hard facts"[quoted in The Norton Anthology, 1988: 1303].

All labels aside, Sexton's poems mostly revolve around one idea: the meaning of being a woman and the female identity [Johnson, 1984: 21]. The puritan upbringing of and parents' influence made Sexton's positions rather unsettled and ambivalent, which denotes the poet's confusion over her role. While she is criticizing the patriarchal society that suppresses the feminine identity, her poems express the poet's "quest for a male authority figure to love and trust." [Kumin: xxix]. Among her rich poetic legacy, Transformations is selected to study the dilemma of feminism in Sexton's poetry, as it is the only work where Sexton searches for material outside her personal psychological traumas and also it is her most successful work critically and aesthetically.

\section{Transformations: Untraditional Fairy Tales}

In seventeen pieces, one introductory and sixteen tales, Sexton retells popular fairy tales that have been major part of world folklore. Like her previous works, Transformations received different criticism from established critics. On one hand, Helen Vendler finds in Sexton's version of the tales an outlet of the poet's "infantile fantasy" [Vendler, 1988: 304], while the entry about the book in The Cambridge Guide to Women's Writing condemns the poet for turning "comforting children's narratives into adult horror stories", framed with "sadly ironic riffs on adult discontents that shift perspective..." [Sage: 629]. On the other, Carol Leventen, considers the volume as part of the "significant body of revisionist/ feminist work" [quoted in DeVito, 2011:+1], and Alicia Ostriker calls Transformation "a brilliant synthesis of public 'story' and psychological revelation", where the poet achieves to bring out a "subversive readings of traditional plots, characters, and morals" [Ostriker, 1982b: 84].

It is true, however, that the comfort of fairy tales, the non-problematic world which they establish, and the soothing tone, all are transformed in Sexton's versions to be more realistic, burdened with social-mockery, and more adultoriented. Rather than starting immediately with her revised tales, Sexton starts her collection with introductory poem, "The Gold Key", in which the poet establishes two major points that pave the way for the altered perspective her following fairy tales present. The first point is the identity of the narrator and her audience. First, identifying the narrator as "a middle-aged witch, me- " [223] $]^{\mathrm{i}}$ disenchants the world of fairy tales: instead of being old-wives tales, narrated by a lovable mother or father figure that assures the listeners the existence of a happy-ending world, Sexton 
tells her readers that the tales will be told by a witch, the figure that mostly comes negative in the traditional fairy tales. The "angry and sardonic perspective" which this narrator provides "determines the shape of the whole collection", and alters the message they reveal to their audience [Harris, 2001: 123].

While the narrator will shift the point of view of narration, hence comes the sarcasm of the tales, the audiences are identified as adult beyond the age of childhood innocence. Alice, one of the listeners is "fifty-six", Samuel is "twentytwo", and the boy who finds the gold key is not a child as in Grimm's tale, but he is sixteen, on the verge of adulthood, and "he wants some answers" [223]. Philip McGowan in his criticism of Transformations believes that there is some correlation between the age of the boy and the number of the transformed fairy tales included in this volume [McGowan, 2004: 74]. The sixteen old boy searching for answers is identified by the poet as being "each of us/I mean you/ I mean me... we must have answers" [223]. Thus, the function of these tales is to provide answers for those who are going to read this book as the key opens

\section{This book of old tales \\ Which transform the Brothers Grimm, \\ Transform? \\ As if an enlarged paper clip \\ Could be a piece of sculpture.}

(And it could).

The answers these tales will provide are presented from different point of view to the traditional versions; these tales are transformations, rather than adaptations [Kumin: xxviii]. It is noteworthy here that Sexton, in her narration of the tales, kept the original plot of the tales but added to them a prologue that links the tale to the modern world, in addition to her sarcastic commentary to peel off the illusion of happy endings that traditional fairy tales support.

To reveal the poet's dilemma over the feminine identity against what society prescribes, the tales are grouped in the following discussions according to the major themes that bring them together.

\section{The Virgin vs. the Witch}

The dilemma of the poet over her feminine identity and her rejection of female image stereotypes dominate three tales in Sexton's collection: "Snow White and the Seven Dwarfs", "Rapunzel" and "Cinderella". The underlying structure is almost the same in these three tales: an innocent girl or princess is captivated by an evil older woman (a stepmother or witch), rescued by a prince and the tale ends by the death or the defeat of the old lady and the happy marriage of the innocent girl and charming prince. In these tales, the narrator criticizes specifically these three elements in these tales: the virgin or innocent girl is portrayed as dumb, as in Snow White, has no value beyond her beauty as in Rapunzel, or she is helpless as in Cinderella. The evil older lady usually receives grotesque punishment that makes the reader wonder if she really deserves that: in Snow White, the wicked queen is forced to put on "red-hot iron shoes" and she is watched burning alive in the wedding of Snow White and her charming prince, Mother Gothel has

$$
\begin{aligned}
& \text { Her heart Shrank to the size of a pin } \\
& \text { Never to say again: hold me, my young dear, hold me, }
\end{aligned}
$$

While the stepmother's destiny is not cleared in Cinderella, the ones who were punished were her stepsisters and again it happens in the wedding ceremony when "the white dove pecked their eyes out", leaving the two women with "two hollow spots" instead of their eyes.

While narrator starts every tale with a prologue that gives the main theme of the tale followed, the strength of the poet's mockery lies in the tone of the happy ending with the union of the prince and the virgin. The ending of Snow White transforms our reading of the tale, detaching the expected feeling of sympathy toward Snow White as a victim of cruel treatment from her stepmother [DeVito: +1]. Snow White ends a queen, caring for her beauty, looking at her mirror like the wicked queen used to do.

$$
\begin{aligned}
& \text { Meanwhile Snow White held court, } \\
& \text { Rolling her china-blue doll eyes open and shut } \\
& \text { And sometimes referring to her mirror as women do. [229] }
\end{aligned}
$$

The union of Rapunzel with her prince charming is given as cliché, quite expected rather than waited for. The narrator, however, puts the union in practical rather than romantic terms, as a necessity to keep the world going:

They lived happily as you might expect

Proving mother-me-do

Can be outgrown,

Just as the fish on Friday, 
Just as tricycle.

The world, some say,

Is made up of couples. A rose must have a stem. [248]

Unlike the other tales, this one tale is rendered as cliché right from the beginning of the narration; it is "that story" which takes people by fortunate accidents from poverty to richness. Cinderella's marrying the prince is like that story of the plumber who wins commercial lottery and rise to fortune, or the nurse "who captures the oldest son's heart./from diapers to Dior/that story", or the milkman whose real estate property makes him wealthy. All these examples the narrator mentions once were poor and rose to fortune with no effort on their part, just like Cinderella who by marrying the prince, "lived, they say, happily ever after", which is an ending that the poet-narrator is not really certain of. The uncertainty of the "happily ever after" concept in relation to marriage is revealed in describing the couple as frozen as "two dolls in a museum case", and the fact that this happily ever after is removed from the reality of daily life.

Cinderella and the prince

Lived, they say, happily ever after,

Like two dolls in a museum case

Never bothered by diapers or dust,

Never arguing over the timing of an egg,

Never telling the same story twice,

Their darling smiles pasted on for eternity

Regular Bobbsey Twins.

That story.[258]

While Sexton is ridiculing the happy-endings and the female stereotypes, the princes of the tales are not exactly as heroic with shinning armors they are known to be. Their rescue of the damsel in distress, which is expected by patriarchal society, happens in Sexton's transformations by mere accidents rather than by their efforts. Their attraction to the heroines of the tales comes at first sight; the dazzling beauty of heroine is the only reason given for their ultimate union. In "Snow White and the Seven Dwarfs", the prince is taken by the beauty in the coffin glass and he cannot leave her side that the dwarfs give him the coffin to keep Snow White in his castle. Her rescue happens by accident, when his guards stumbled dropping the coffin and thus letting the apple out of her throat. She wakes up "miraculously" [228]. Immediately, after her awakening, the wedding happens.

In "Rapunzel", the prince was passing by, enchanted by the voice of the maiden in distress, he managed by deception to climb his way to the castle and once he meets Rapunzel, "he declared his love." The prince in this tale does try to help Rapunzel to be free, but his efforts are futile, and after losing his sight and wandering for years searching for her, he accidently finds her and the tears of his heroine cures his blindness. In "Cinderella", it happens twice that the prince almost marries the wrong daughter, and if it isn't for the white dove, he would end up with the eldest stepsister. The prince in this story is basing his search for a wife on the size of the shoe, regardless of the other characteristics that Cinderella may have.

\section{Female vs. Male}

Though Sexton's version of fairy tales is not exactly about the male-female conflict, which is recurrent in feminist literature [Ostriker, 1982b: 86], some of the tales do present the male figure as domineering and a threat to the heroine ultimate happiness. Under this title, three major tales revolve around this theme: "The Maiden without Hands", "The Twelve Dancing Princess" and "Briar Rose". In each of these tales, the female heroine is victimized by the male figures in her life: the father and the husband. Unlike the tales discussed above, the tales discussed in this section highlight one of the recurrent themes in feminist literature, namely, the negative influence of patriarchy as symbolized by the two male figures that can affect a woman's life: the father and the husband.

In "The Maid without Hands", male authority plays major role in affecting the heroine life and the effect is not exactly positive. The narrator starts the poem with a question around which revolves the theme of the tale:

$$
\begin{aligned}
& \text { Is it possible } \\
& \text { he marries a cripple } \\
& \text { out of admiration? [273] }
\end{aligned}
$$

The answer is in "the desire to own the maiming" to fulfill their heroic image. The tale of the maiden falls in this category where a king is attracted to his wife as long as she is without hands and depending on him, but when she finally has her hands back, and thus becomes more independent, she loses her charm. However, Sexton's version holds more to the reader; after giving the prologue that summarizes the theme of the poem, the narrator highlights another feminist theme, namely the negative influence of the father figure. The maiden is maimed by her own "cruel father/ who 
cut off his daughter's hands/ to escape from the wizard" who gave the father abundant wealth. However, the maiden leaves her father's house and "wandered in forbidden woods" which belongs to "the good, kind king". The maiden suffers from her handicap, unable to perform simple tasks, and now being in the wood she tries in vain to eat some fruit: "she was, I'd say/ without resources". Being helpless as she is, the king sees her and decides to take her for a wife, a heroic act that won him the admiration of his people. The wizard appears again to ruin the maiden happiness when he changes the message sent to the king about his new born child. The king, again, acts heroically and accepts his child bravely whom he is told to be "a changeling". The wizard could not let the maiden in peace, and interferes again; the message of the king is changed to

\title{
Kill both \\ Then cut out her eyes and send them, \\ Also cut out his tongue and send it; \\ I will want my proof. [275]
}

Woman stands for other women and that is what the mother of the king does as she asks the queen to take her son and run away to the woods. The devotion of the maiden in the wood has her hands grow again and as the king is "good and kind", he finds them after searching seven years for them. Up to this point the story follows the original plot of Grimm's fairy tales; the twist comes when the king realizes that his handless queen does not need his silver hands any more. Her hands now are "unfortunately whole".

Now the butchers will come to me,
He thought, for I have lost my luck.
It put an insidious fear in him
Like a tongue depressor held fast

At the back of your throat. [276]

The reaction of the king is quite strange: he should have been happy that his wife is no longer maimed, but the contrary happens that he has to make "the best of it", and accepts her wholeness as "a switch hitter", a baseball batter who has to deal with different situations. The image of their happy ending is blemished by keeping the silver hands like a testimonial badge for the kindness of the king

\author{
All their lives they kept the silver hands \\ Polished daily, \\ A kind of purple heart, \\ A talisman, \\ A yellow star. [276].
}

In "Twelve Dancing Princesses", the twelve girls enjoy night journeys to a fantastical world that can exist only in imagination and are forced by their father and his hired man to step down to reality.

Anne Sexton starts "Twelve Dancing Princess" with a rhetoric question: "if you danced from midnight/ to six A.M. who would understand?" The answer to this question is a list of people undermined or pressed by reality and in bad need for some escape: the runaway boy, the paralytic's wife, the amnesiac, the drunken poet, the insomniac and the night nurse. All these can understand why the twelve princesses escape every night their father's "locked and bolted" palace to wear off their shoes in all-night dance. Princes try, fail and get killed till a poor solider decides to try his luck there. Pretending to be asleep and with the help of the invisible cloak given to him by the old woman he met on his way, the poor man succeeds to solve mystery, following the princesses in their underground journey to the enchanting world of silver and diamond trees, a lake and twelve "enchanted princes" with twelve boats ready to take the girls to dance. The solider follows taking evidence from the places the princesses go to during the night and by the morning, he hurries to the king, whom the narrator calls as "Sphinx" symbolizing his rigidity and control. They triumph over the princesses and put an end for their runaway journeys. The happy ending expected in fairy tales is not exactly happy but one that denotes the end of the princesses' happiness with the victory of the male figure:

He had won. The dancing shoes would dance

No more. The princesses were torn from

their night life like baby from its pacifier.

Because he was old he picked the eldest.

At the wedding the princesses averted their eyes

And sagged like old sweatshirts.

Now the runaways would run no more and never 
Again would their hair be tangled into diamonds,

Never the bed falling down into purgatory

To let them climb in after

With their Lucifer kicking. [281]

While the father figure maimed his daughter for life in "The Maiden without Hands", and brings his daughters back to the overwhelming reality and ending their joyful night journeys to the world of dreams, the father in "Briar Rose" which ends Transformation horrifies his daughter with his inappropriate advances.

"Briar Rose (Sleeping Beauty)" tells one of the most known tale of that sleeping princess who awakens after centuries of sleeping with a kiss from prince charming. However, Sexton starts her tale with a prologue asking her readers to "consider" a girl who is shocked and currently under therapy because of childhood trauma which turns to be sexual abuse by her father. Following that, the tale goes on along the traditional plot line of sleeping beauty where a witch curses the new born princess to long sleep. Sexton's version of the fairy tales does not mention the awakening charm of the kiss to awaken the princess, and draws the attention to the protective father who

$$
\begin{aligned}
& \text { fastened the moon up } \\
& \text { With a safety pin } \\
& \text { To give her perpetual light } \\
& \text { He forced every male in the court } \\
& \text { To scour his tongue with Bab-o } \\
& \text { Lest they poison the air she dwelt in. [292] }
\end{aligned}
$$

Part of fatherly protection is pushing all males away, but in Sexton's tale the father sounds possessive of his daughter whom he wants for himself

Thus she dwelt in his odor.

Rank as honeysuckle. [292]

The curse happens at her fifteenth birthday as the traditional fairy tale goes when all goes to sleep, waiting for prince charming to awaken the sleeping beauty. Many tried but none succeeded till hundred years later a prince succeeds to go through; he is presented as savior figure, a Moses who saves Briar Rose. When she awakens she calls "Daddy! Daddy", calling for father's protection, but she is set free to marry the prince and "all went well".

However, the happy ending is ruined by the awakened princess' fear of sleep, her persistent insomnia, and "never in the prince's presence". The rest of the tale is actually a confessional piece on the part of the princess who reveals why she hates sleep. The girl's trauma does not come from sleeping; her memories and dreams bring that incident of being raped by her father and now she cannot be in normal relationship with any man now.

This trance girl

Is yours to play with.

You could lay her in a grave,

An awful package,

And shovel dirt on her face

And she'd never call back: Hello there!

But if you kissed her on the mouth

Her eyes would spring open

And she's call out: Daddy! Daddy! [294]

\section{Male vs. Female}

It appears that Sexton is not quite decided when it comes to the image of the male figure, be it a father or a husband. While some of her fairy tales warn females against male domination, another group of her fairy tales brings males to more positive lights while pushing females to the negatives. In "White Snake" and "The Little Peasant", the male figure tries to overcome women's desire for power, women's frailty and contempt. In each of these poems, the protagonist is a male who tries to find his place in the world against some woman's domination.

"The White Snake" has not received much attention from critics: in the context of feminist literature, where poems are written to criticize stereotypes and male oppression against women, "The White Snake" supports the opposite arguments against women's playfulness and cruelty. That is why most of the studies on Transformations focus on those 
poems which record Sexton's feminist stands toward female stereotypes, like "Cinderella", "Snow-White" and "Rapunzel", on the expense of such poems that reveal women's dark nature. The poem progresses through two moves: the first revolves around growing wise and the second about marriage. In the first part, a boy takes a bite from the secret dish of the king he serves and gains the talent of understanding animals' sounds. The narrator-witch, or Sexton's alterego, starts her tale by referring to these times when she used to hear animals talking to her, when she used to have the "voice of the spirits" inside and "an epileptic aura" surrounding her; these were the time when she was not singing alone. From the first part of the tale, we can infer that what seems to be madness, Sexton considers as a gift, a talent that gives wisdom.

The story goes as the following: a poor servant once decides to take a bite from the king's secret dish, which was a white snake, a "furtive weed" that kept the king wise. Once the boy ate from the snake, he starts to hear "the animals/ in all their voices speak." In her description of the newly-gained talent, Sexton recalls images of people admitted to "a building/ with no exit", a reminiscent image of the mental institution as this new talent sounds like madness more than a gift.

Then the wise boy decides to travel and in his travels he helps many animals which give him in exchange of his help promises to return the favor when he needs it. In his next stop, he arrives at a town in which there is a contest to marry the princess: Sexton deletes the character of the king, the princess father, who was the one to set the contest in the original fairy tale, and instead Sexton puts the princess in charge from the beginning in setting the three contests. The king in the original tale stands with his daughter who keeps setting contests for the suitor; his role is confusing in the female vs. male conflict and probably this is why Sexton deleted his character.

The princess appears as a cruel vain woman for whose hand fifty men paid their lives while searching for the ring she has thrown into the sea. Her reactions are cold to the traveler's vows of love.

\author{
the servant was stage-struck. \\ Nail me to the masthead, if you will, \\ and make a dance all around me. \\ Put on the gramophone and dance at my ankles. \\ But the princess smiled like warm milk \\ and merely dropped her ring into the sea. \\ If he could not find it, he would die; [231]
}

Moreover, the narrator puts the princess' playfulness with the man's life when she sets new contest as a universal characteristic of woman: she is a woman, that is why it is not enough for her that the man brings her ring from the depth of the sea, and being just like Eve, she is not yet satisfied when the traveler achieved the impossible task of gathering within one day the grains that she has to demand the apple of life for which he searches for two years, bearing all the risks till he comes back with what she is in "hunger for".

In the ending note of the poem about the union of the princess with the wise man, the narrator revives her usual cynicism of marriage as failing institution that strips people of their souls:
They played house, little charmers
exceptionally well.
So, of course,
they were placed in a box
and painted identically blue
and thus passed their days
living happily ever after -
a kind of coffin,
a kind of blue funk.
Is it not?

"The Little Peasant" is another poem that puts male characters in more positive light opposite to more negative roles for women. In the original tale, the focus is on the peasant who tricks people in small town to drown themselves and thus become their sole heir of their fortunes. However, Sexton's interest in female-male relationships shifts the story's focus to the miller's wife and her unexplained adultery which cast her into more negative light in the moral context [Colson, 2011: 133]. The narrator's attitude toward the subject is made clear starting with the prologue which though blames both sexes, but the reader can sense that the speaker is singling out women and highlight a negative light around their sins. 
Oh how the women

grip and stretch

fainting on the horn.

The men and women

cry to each other.

Touch me,

my pancake,

and make me young. [237]

The prologue is not long or brings many examples as it is the case with the other tales. The narrator immediately starts with the miller's wife and the parson as her examples of an adultery case. Though the poem did not receive much attention from critics, but the way Sexton manipulates the story can be interpreted as casting light on her own sense of guilt for her several adulteries and in compensation for that guilt, she puts her heroine within negative context unlike her other heroines.

The other poem that casts relative negativity on the female more than the male figures is "The Frog Prince", where the princess appears manipulative making false promises to the frog to have her lost ball back. Once she regains what she has lost with the help of the frog, she refuses to fulfill her promises because she is disgusted with it. It is her father, a male figure who has been condemned in other fairy tales like "Maiden without Hands" and "Briar Rose", who "forced her to comply" with her promises to the frog.

However, many critics ignores the negativity cast on the princess character and prefer to concentrate on the sexual references which the prologue provides. Kumin finds "Oedipal explorations" in the poem because of the reference to the frog as representing the princess' father's sex organs [xxviii]. Though such interpretation may hold some credibility, the manipulative character of the princess asks the readers to pause and contemplate the context of the poem in relation to the whole collection. What is exactly the narrator trying to say with the collection of the tales in general, and in this poem in particular? If some poems mock the patriarchal society and the female stereotypes in fairy tales, why is she presenting females in such negative light, that a reader may sympathize or admire the male character instead?

While the narrator condemns deception in "The Red Riding Hood", as represented by the wolf, she presents another deceptive female in "Rumpelstiltskin" where a girl asks the help of a dwarf, agreeing on his conditions, though she intends to deceive the dwarf right from the beginning

Give me your first born

And I will spin.

She thought: Piffle!

He is silly little man.

And so she agreed. [235]

Sexton gives further credit to male characters in several tales that revolve basically and mostly on male figures while there is minimum or no existence of females. Tales like "Godfather Death" and "Iron Hans" put positive and heroic males on the foreground and restore faith in the ideals of the fairy tales.

Although Sexton opens the poem with a challenging confrontation to death, calling it "Mister tyranny", there is nothing in the rest of the poem that suggests the symbolism of death as male domination as some researchers tend to assume. ${ }^{\text {ii }}$ For Sexton, death is not a tyrant that she is afraid of: her many attempts of suicide prove that she finds death as salivation. Besides, within the context of the story, the physician challenges death for the sake of the princess even if it means that he is going to pay his own life for it. Death threatened the physician not to challenge him again after saving the king who is supposed to die, but saved by the doctor in direct defiance of his "godfather". However, when the next patient was the princess whom he fallen in love with (another instance of first-sight love which Sexton satirized in her tales), the physician defied his godfather and saved the princess and paid his life for this as the tale ends with death dragging his godson to the underworld and putting out his candle.

Godfather death

Turned him over like a camp chair

And fastened a rope to his neck

And led him into a cave....

And Godfather death, as it is written,

Put a finger on his back

For his blackout,

The big no. [244] 
In "Iron Hans", another example of man's heroism is introduced with the risk of blemishing the female image as a victim of masculine society. In this tale, the narrator starts her prologue by counting couple of examples for people who are considered "lunatic" by society. These examples serve to set the ground for the point she will make later which asserts the deception of appearances: Iron Hans when discovered by the people was considered a "lunatic" and dangerous enough to be kept prisoned in a cage. However, this creature turns to "a proud king" [254] in the wedding of the boy who sets him free with his pure heart and loyalty. The main frame of the story revolves around the friendship that grows between these two men: the boy sets Iron Hans free and follows him to the enchanted forest. The latter sends the boy back to the world when he fails to keep his word and stay away from the golden pool. However, when the boy needs the help of Hans, the latter fulfills his promises and helps the boy till he gains back his royal status and marries the beautiful princess. The courage, loyalty and the friendship of the two sets Iron Hans free from his spell: the narrator takes the reader back to her prologue by empathizing that the transformation of Hans back to being normal does not happen with the help of medicine nor electroshocks, but a pure loving heart.
When I was a wild man,
Iron Hans sad,
I tarnished all the world.
I was the infector...
But you have saved me
From the awful babble
Of that calling. [255]

Presenting male characters in positive light, by shedding light on their heroism and by adopting a language less cynical than the ones used in the tales with female heroines, Sexton breaks major rules of feminism which is known for attacking masculine figures and celebrating more positive and heroic characteristics in females. It appears that Sexton, which is known for her strong stands of feminism against male domination, lives a dilemma in Transformations: she is a feminist in the way she criticizes conformists images of women and ridicules the values of patriarchal society of marriage and prince charming, yet she is also condemns women as being participants in their won slavery when they accept these values, and when they do not stand for each other. She also expresses a conformist voice when she condemns women as femme fatal figures and put men on the pedestal of heroism.

\section{References}

Colson, J. (2011). Anne Sexton's "The Little Peasant". The Explicator 69 (3): 133-136.

Dalfonzo, Gina, (2013). Frozen's Cynical Twist on Prince Charming. The Atlantic (20 February, 2014). Available at: http://www.theatlantic.com/entertainment/archive/2013/12/-em-frozen-em-s-cynical-twist-on-prince-charming/282204/

DeVito, J. (2011). The Transformations of Anne Sexton, Poststructuralist Witch, The Essay Exchange at I love Literature. iloveliterature.com, 25 August 2011. Web [20 March 2014], http://www.iloveliterature.com/anne_sexton_essay.html

Fukuda, Sh. (2008). The Hesitancy of "middle-aged witch": Anne Sexton's Transformation. Revista de Estudios Norteamericanos, no. 13, pp. 31 - 47.

Gill, J. (2006). Modern Confessional Writing: New Critical Essays. New York: Routledge.

Gill, J. (2004). Textual Confessions: Narcissism in Anne Sexton's Early Poetry. Twentieth Century Literature 50 (1): 59-87.

Harris, E.W. (2001). New Frames of Old Tales. Twice Upon a Time: Women Writers and the History of Fairy Tales. New Jersey: Princeton University Press: 121-134.

Johnson, G. (1984). The Achievement of Anne Sexton. Hollins Critic 21 (3): +1

Joyce, C.M. (2009). Contemporary Women Poets and the Fairy Tales. Susan Redington Bobby (ed.), Fairy Tales Reimagined: Essays on New Retellings. North Carolina: McFarland: 31-43.

Kimmelman, B. (2005). Companion to $20^{\text {th }}$ Century American Poetry. New York: Facts on File Inc.

Kumin, M. (1981). How It Was: Maxine Kumin on Anne Sexton. The Complete Poems: Anne Sexton: xix-xxxiv.

Mathew, R. (2011). Re-Vision as Art and Medium: A Study of Re-Visionist Mythmaking in Feminist English Poetry. Sree Sankaracharya University of Sanskrit, PhD thesis.

McGowan, P. (2004). Anne Sexton and Middle Generation Poetry: the Geography of Grief. Connecticut: Greenwood Publishing.

Middlebrook, D.W. (1996). Telling Secrets. The Seduction of Biography, by Mary Rhiel and David Suchoff (eds.). New York: Routledge: 123-129.

Ostriker, A. (1982a). That Story: Anne Sexton and Her Transformation. American Poetry Review, July/Agust: 11-16. 
, (1982b). Thieves of Language: Women Poets and Revisionist Mythmaking. Signs 8 (1): 68-90.

Sage, L. (ed.), (1999). The Cambridge Guide to Women's Writing in English. Cambridge, Cambridge University Press. Sexton, A. (1981). The Complete Poems: Anne Sexton. Boston: Houton.

Vendler, H.(1988). The Music of What Happens: Poems, Poets, Critics. Boston: Harvard University Press.

\footnotetext{
${ }^{\text {i }}$ All quotations of Anne Sexton's poems are taken from Collected Poems, 1982

ii Shiho Fukuda, 2008, reads "death" in Sexton's poem as "a male who must be obeyed"[p.40], and Rani Mathew, 2011, suggests that by calling death "mister tyranny", Sexton "challenges the pervading dictatorial tone of patriarchy in the institutions of both religion and family" [p. 267].
} 